УДК 341.215 .4

DOI https://doi.org/10.32844/2618-1258.2019.3-2.44

СИРОїд Т.Л.

\title{
МІЖНАРОДНИЙ ОРГАНІЗАЦЙНО-ПРАВОВИЙ МЕХАНІЗМ ЗАБЕЗПЕЧЕННЯ ПРАВА НА ЗДОРОВ'Я ОСІБ ПОХИЛОГО ВІКУ
}

\begin{abstract}
У статті проаналізовано положення міжнародно-правових актів універсального й регіонального характеру, якими гарантовано право кожної людини на найвищий досяжний рівень фізичного і психічного здоров'я, незважаючи на вік, стать та інші чинники, зокрема розкрито положення таких актів, як Загальна декларація прав людини 1948 р., Міжнародний пакт про економічні, соціальні й культурні права 1966 р., Факультативний протокол до Міжнародного пакту про економічні, соціальні й культурні права 2008 р., Резолюція 70/1 Генеральної Асамблеї «Перетворення нашого світу: Порядок денний у галузі сталого розвитку на період до 2030 р.» від 27 вересня 2015 р., Резолюція Ради з прав людини, що стосуються здійснення права кожної людини на найвищий досяжний рівень фізичного і психічного здоров'я, Зауваження загального порядку Комітету з економічних, соціальних і культурних прав, що стосується питань здоров'я, Свропейська соціальна хартія (переглянута) 1996 р., Хартія основних прав Європейського Союзу 2000 р. Охарактеризовано положення спеціальних угод, що безпосередньо стосуються літніх людей, зокрема Принципи ООН щодо осіб похилого віку 1991 р., Декларацію з проблем старіння 1992 р., Мадридський міжнародний план дій з проблем старіння 2002 р. тощо.

Зважаючи на ту обставину, що на міжнародному універсальному й регіональному рівнях функціонують інституційні органи та посадові особи, до компетенції яких зараховано захист прав людини, зокрема осіб похилого віку, проаналізовано практику Європейського суду з прав людини, розкрито повноваження Комітету з економічних, соціальних і культурних прав, охарактеризовано мандат Спеціального доповідача 3 питання про право кожної людини на найвищий досяжний рівень фізичного і психічного здоров'я, розкрито процедуру розгляду ним індивідуальних скарг.

На підставі аналізу міжнародно-правової основи в галузі захисту прав людини, зокрема осіб похилого віку, зроблено відповідні висновки й надано рекомендації, спрямовані на вдосконалення положень міжнародних угод; підкреслено роль і значення міжнародних інституцій у галузі захисту цієї категорії осіб.
\end{abstract}

Ключові слова: захист, здоров'я, інститучійні органи, особи похилого віку, правова основа.

The article analyses the provisions of international legal acts of universal and regional nature, which guarantee the right of every person to the highest attainable level of physical and mental health, regardless of age, gender and other factors, in particular, the provisions of the following acts are disclosed: Universal Declaration of Human Rights of 1948, International Covenant on Economic, Social and Cultural Rights of 1966, Optional Protocol to the International Covenant on Economic, Social and Cultural Rights of 2008, Resolution adopted by the General Assembly on 25 September 2015 A/RES/70/1 Transforming our world: the 2030 Agenda for Sustainable Development, Human Rights Council resolutions on the exercise of the human right to the highest attainable level of physical and mental health, General Comments of the UN Committee on Economic, Social and Cultural Rights on health issues, European Social Charter (revised) of 1996, Charter of Fundamental Rights of the European Union of 2000. The provisions of special agreements directly applicable to the older persons are described, particularly: United Nations Principles for Older Persons of 1991, Declaration on Aging of 1992, Madrid International Plan of Action on Aging 2002.

(C) СИРОЇД Т.Л. - доктор юридичних наук, професор, завідувач кафедри міжнародного і європейського права (Харківський національний університет імені В.Н. Каразіна) 
Considering the fact that at the international universal and regional levels institutional bodies and officials are responsible for the protection of human rights, in particular, the rights of older persons, the case law of the European Court of Human Rights is analysed, the powers of the Committee on Economic, Social and Cultural Rights, the mandate of the Special Rapporteur on the right of every person to the highest attainable level of physical and mental health is characterized, and the procedure for considering individual complaints is disclosed.

Based on the analysis of the international legal framework in the field of human rights protection, in particular, of older persons, relevant conclusions and recommendations are made aimed at improving the provisions of international agreements; the role and importance of institutional international bodies in protecting the rights of this category of persons is emphasized.

Key words: protection, health, institutional bodies, older persons, legal basis.

Вступ. Право на досягнення найвищого життєвого рівня (право на здоров’я) є одним із основних прав людини, юридично закріплених на міжнародному, регіональному та національному рівнях. Воно гарантоване численними міжнародними актами в галузі прав людини, серед яких чільне місце посідають міжнародні універсальні акти, такими як Загальна декларація прав людини 1948 р., яка проголосила право кожної людини на такий життєвий рівень, включаючи їжу, одяг, житло, медичний догляд і необхідне соціальне обслуговування, що є необхідним для підтримання здоров'я й добробуту іiї самої та ії сім'ї (ч. 1 ст. 25) [1], Міжнародний пакт про економічні, соціальні й культурні права 1966 р., у якому держави-учасниці визнали право кожної людини на найвищий досяжний рівень фізичного і психічного здоров'я та взяли на себе зобов'язання щодо реалізації такого права шляхом, зокрема, створення умов, які забезпечували б усім медичну допомогу й медичний догляд у разі хвороби (ч. 1, п. d ч. 2 ст. 12) [2], Резолюція 70/1 Генеральної Асамблеї «Перетворення нашого світу: Порядок денний у галузі сталого розвитку на період до 2030 року» від 27 вересня 2015 р., яка визначила необхідність забезпечення здорового способу життя і сприяння благополуччю для всіх у будь-якому віці однією з цілей у галузі сталого розвитку (мета 3). Крім цього, у розробленій у межах саміту ООН щодо прийняття порядку денного в галузі розвитку на період після 2015 р. Декларації глави держав та урядів визнали, що задля зміцнення фізичного і психічного здоров'я, підвищення добробуту і збільшення середньої тривалості життя для всіх варто забезпечити населення медичною допомогою та гарантувати доступ до якісного медичного обслуговування (п. 26) [3]. Низку резолюцій, що стосуються здійснення права кожної людини на найвищий досяжний рівень фізичного і психічного здоров'я, прийнято Радою $з$ прав людини: 6/29 від 14 грудня 2007 р., 15/22 від 27 вересня 2010 р., 24/6 від 8 жовтня 2013 р. тощо. Серед регіональних актів варто вказати Європейську соціальну хартію (переглянуту) 1996 р., відповідно до якої держави взяли на себе зобов'язання щодо надання соціальної та медичної допомоги (ст. 13). Право на охорону здоров'я гарантовано також Хартією основних прав Європейського Союзу 2000 р. (ст. 35).

Зважаючи на ту обставину, що серед категорій осіб, які потребують підвищеної уваги у сфері медичної допомоги, є така вразлива категорія, як особи похилого віку, в положеннях міжнародних актів у галузі прав людини приділили окрему увагу питанню забезпечення права на охорону їхнього здоров’я. Так, у Декларації з проблем старіння (Резолюція 47/5 від 16 жовтня 1992 р.) Генеральна Асамблея ООН визнала, що особи похилого віку мають право прагнути до найкращого стану здоров'я й добиватися його [4]. Право осіб похилого віку на доступ до медичного обслуговування, що дає їм змогу підтримувати або відновлювати оптимальний рівень фізичного, психічного та емоційного благополуччя й запобігати початку або стримувати початок періоду недуг, також закріплено в Принципах ООН щодо осіб похилого віку 1991 р. (п. 11) [5]. У прийнятому у 2002 році Мадридському міжнародному плані дій з проблем старіння підтверджено право осіб похилого віку на доступ до профілактичного та іншого лікування. При цьому акцентовано увагу на тому, що зміцнення здоров'я населення та профілактика захворювань протягом усього життя повинні бути орієнтовані на збереження самостійності в догляді за собою, а системи охорони здоров'я та надання медичних послуг мають включати необхідну підготовку кадрів і створення установ, які відповідають особливим потребам населення похилого віку (п. 58) [6]. Держави-учасниці Європейської соціальної хартії (переглянутої) 1996 р. зобов’язалися вживати відповідних заходів або заохочувати заходи для забезпечення медичного обслуговування 
та послуг, яких вимагає стан здоров'я осіб похилого віку (ст. 23) [7]. У Хартії основних прав Європейського Союзу 2000 р. зазначено, що Європейський Союз (далі - СС) визнає й поважає право людей похилого віку вести гідне та незалежне життя й брати участь у соціальному та культурному житті (ст. 25) [8].

Незважаючи на такий грунтовний правовий масив актів, що стосуються захисту прав літніх людей, варто вказати, що суттєвим недоліком правового регулювання захисту цієї категорії осіб є відсутність універсального міжнародно-правового акта, свого роду Хартії прав літніх людей, який містив би весь перелік гарантованих прав. Крім того, в прийнятих актах універсального й регіонального рівнів також відсутні конкретні положення, що стосуються літніх осіб, наприклад, такі, які існують щодо інших категорій вразливих осіб, зокрема жінок, дітей, інвалідів і трудящих-мігрантів.

Виходячи з вищеозначеного, варто констатувати, що обрана тема дослідження є актуальною. Питанням дослідження прав людини в різних аспектах присвячено низку робіт українських і зарубіжних дослідників, а саме: М. Буроменського, М. Баймуратова, Д. Кларк (D. Clark), T. Лінч (T. Lynch), Л. Радбрух (L. Radbruch), C. Сентено (C. Centeno), Л. Фоміної та ін. Разом із тим необхідно констатувати, що тематика міжнародної організаційно-правової основи забезпечення права на здоров'я осіб похилого віку не знайшла достатнього висвітлення в роботах науковців.

Постановка завдання. Виходячи з вищеозначеного, робота має на меті аналіз міжнародного організаційно-правового механізму забезпечення права на здоров'я літніх людей.

Результати дослідження. Приступаючи до викладення основного матеріалу, необхідно зазначити, що в міжнародних актах універсального й регіонального характеру з прав людини містяться загальні положення щодо регламентації права на здоров'я, його детально розтлумачено в Зауваженні загального порядку №14 Комітету з економічних, соціальних і культурних прав, яким зазначено, що право на здоров'я включає в себе не тільки право на своєчасні та адекватні послуги в галузі охорони здоров'я, а й на такі основоположні передумови здоров'я, як доступ до безпечної питної води й адекватні санітарні послуги, безпечні умови праці й навколишнього середовища, а також доступ до освіти та інформації в галузі здоров'я, в тому числі статевого й репродуктивного здоров'я. Право на здоров'я включає в себе як свободи, так і суміжні права. До свобод належить право на контроль за своїм здоров'ям, включаючи право не піддаватися без вільної згоди медичному лікуванню або науковим дослідам. До похідних прав належить право на систему охорони здоров'я (а саме медичне обслуговування й основоположні передумови здоров'я), що забезпечує людям рівні можливості в прагненні до вищого досяжного рівня здоров'я. Комітетом підтверджено важливість комплексного підходу, що поєднує елементи профілактичного, лікувального й реабілітаційного медичного обслуговування. Такі заходи мають грунтуватися на періодичних оглядах осіб обох статей; заходах щодо фізичної та психологічної реабілітації з метою збереження функціональності й самостійності літніх людей; на увазі хронічно та невиліковно хворим особам і догляді за ними, полегшенні в міру можливості їхніх страждань і надання їм можливості гідно піти з життя (п. 25) [с. 113].

Забезпечення права на здоров'я здійснюється відповідно до зобов'язань держав-учасниць того чи іншого договору. Зокрема, Міжнародний пакт про економічні, соціальні й культурні права покладає на держави-учасниці зобов'язання вжити в максимальних межах наявних ресурсів заходів, щоб забезпечити поступово повне здійснення визнаних у цьому Пакті прав усіма належними способами, включаючи, зокрема, вжиття законодавчих заходів (ч. 1 ст. 2) [2].

Комітет з економічних, соціальних і культурних прав також визначив зобов'язання держав-учасниць щодо забезпечення здійснення права на здоров'я на національному рівні. До них належать такі зобов'язання: держави несуть зобов'язання поважати право на здоров'я, зокрема утримуючись від уживання заходів, що перешкоджають або обмежують рівний доступ усім, у тому числі ув'язненим або тим, що утримуються під вартою, представникам меншин, особам, які просять притулку, і незаконним іммігрантам, до профілактичних, лікувальних і паліативних послуг охорони здоров'я, утримуючись від зведення дискримінаційної практики в ранг державної політики, а також від дискримінаційного ставлення до здоров'я жінок і їхніх життєвих потреб у цій галузі.

Зобов'язання захищати передбачає, зокрема, відповідальність держав за прийняття законодавчих або інших заходів, що забезпечують рівний доступ до послуг охорони здоров'я та інших пов'язаних з охороною здоров'я послуг третіми особами. Держави повинні стежити також за тим, щоб треті сторони не обмежували доступ населення до інформації та послуг, що стосуються здоров'я. 
Зобов’язання здійснювати вимагає, зокрема, від держав-учасниць відводити чільне місце праву на здоров'я в національних політичних і правових системах, переважно на законодавчому рівні, а також розробити національну політику охорони здоров'я з детальним планом здійснення права на здоров'я. Це зобов'язання передбачає також прийняття державою позитивних заходів, що забезпечують окремим особам і громадам можливість і сприяння їм у користуванні правом на здоров'я.

Серед невідкладних зобов’язань держав Комітетом зазначено гарантії недискримінації та рівного ставлення, а також зобов'язання приймати навмисні й конкретні заходи, спрямовані на повне здійснення права на здоров'я, такі як підготовка загальнонаціональної державної стратегії і плану дій у галузі охорони здоров’я. Прогресивне здійснення означає, що держави-учасниці мають конкретне зобов'язання триваючого характеру якомога оперативніше й ефективно просуватися по шляху до досягнення повного здійснення права на здоров'я [9, с. 106].

Суттєвою гарантією права на здоров'я є наявність інституційної основи захисту. Серед таких інституційних механізмів варто зазначити Свропейський суд з прав людини (далі - ССПЛ) судовий орган у системі контролю за дотриманням Конвенції про захист прав людини і основоположних свобод 1950 р. (СЄД № 005) і протоколів до неї, оснований державами учасницями Ради Європи. Основні положення, що регулюють діяльність ЄСПЛ, визначають його внутрішню структуру, передбачені Конвенцією 1950 р. [10]. Суб'єктами подачі скарги до ЄСПЛ є: 1) будьяка договірна сторона щодо будь-якого передбачуваного порушення Конвенції і протоколів до неї іншою договірною стороною; 2) фізичні особи, неурядова організація або група приватних осіб, які стверджують, що стали жертвами порушень однією з договірних сторін їхніх прав, передбачених Конвенцією чи додатковими протоколами до неї. У цьому випадку договірні сторони зобов'язуються не створювати перешкод для ефективної реалізації цього права. Критеріями прийняття заяв до розгляду ССПЛ є факт використання всіх національних засобів захисту відповідно до загальновизнаних норм міжнародного права й дотримання встановленого строку, який обчислюється з дати прийняття остаточного рішення на національному рівні. ЄСПЛ не розглядає індивідуальні заяви у випадках: якщо вони анонімні; за своєю сутністю заява порушує питання, що вже розглянуто ЄСПЛ або вже розглядалося шляхом іншої процедури міжнародного розслідування чи врегулювання й не містить нової відповідної інформації; якщо заява, на думку ЄСПЛ, несумісна з положеннями Конвенції або протоколів до неї; явно необгрунтована або є зловживанням правом на оскарження [11]. Згідно зі ст. 46 Конвенції, Договірні сторони зобов’язуються виконувати рішення ЄСПЛ.

Справедливості ради необхідно акцентувати, що Конвенцією 1950 р. не передбачено окремої статті, яка б гарантувала право на здоров'я, що є суттєвим недоліком у правовому регулюванні, однак практика ЄСПЛ свідчить про те, що скаржники посилаються на порушення інших статей Конвенції. Наочною є справа Volintiru проти Imалії (заява № 8530/08). Заява надіслана італійському уряду 19 березня 2013 р. Обставини справи: у лютому 2007 р. у віці 85 років матір заявника було доправлено до лікарні на підставі того, що в неї виявили гіпоглікемію, що супроводжувалася серйозними неврологічними пошкодженнями, коматозним станом, одночасною наявністю інфекції крові лівої легені та сечогінним блокуванням. Приблизно через місяць лікарі вирішили, що ii варто виписати з лікарні (незважаючи на те що стан іiі здоров'я ще вважався серйозним, було констатовано незначне покращення і її стан визнали як стабільний). 10 березня 2007 р. жінка була доставлена до медичного відділення в комі, а 19 березня 2007 р. вона померла. Заявник скаржився на те, що його мати не отримала необхідного лікування задля захисту їі життя. Він також стверджував, що погані умови в лікарні спричинили інфекцію, яка призвела до смерті, та скаржився на відсутність ефективного національного розслідування в цій справі. ЄСПЛ повідомив про заяву італійський уряд і порушив справу відповідно до ст. ст. 2 (право на життя), 3 (заборона нелюдського або принизливого поводження), 8 (право на повагу до приватного та сімейного життя) і 35 (критерії прийнятності) Конвенції з прав людини [12, с. 1].

У справах Scoppola проти Iталії (заява № 50550/06), Cara-Damiani проти Iталії (заява № 2447/05), Contrada проти Imaлiї (№ 2) (заява № 7509/08) мова йшла про нелюдське та/або принизливе поводження, якого зазнали заявники, яких було ув'язнено, незважаючи на неможливість надавати їм у в'язничному середовищі необхідну медичну допомогу через наявність у них серйозних патологій. Вони свідчили про невідповідність матеріальних умов утримання забезпеченню здоров'я, а один із заявників акцентував на порушенні ст. 3 - забороні катування. На виконання рішення ССПЛ заявників було поміщено під домашню варту. Крім того, у 2015 р. прийнято Керівні принципи щодо питань забезпечення охорони здоров'я в тюремних закладах для 
дорослих і функціонування національних і регіональних мереж охорони здоров'я, які спрямовані на покращення координації та подолання регіональних відмінностей у наданні медичної допомоги ув'язненим за допомогою таких заходів, як, наприклад, акредитація медичних працівників для ув'язненого населення, а також запровадження системи моніторингу якості медичної допомоги, що надається ув'язненим [13, с. 3-4].

Комітет з економічних, соиіальних $і$ культурних прав є органом незалежних експертів, що спостерігають за виконанням державами-учасницями Міжнародного пакту про економічні, соціальні й культурні права 1966 р., який покладає зобов'язання на держави-учасниці вживати заходи індивідуально й через міжнародну допомогу та співробітництво в максимальних межах наявних у нього ресурсів з метою поступового досягнення повної реалізації економічних, соціальних і культурних прав [14]. Комітет засновано відповідно до Резолюції ЕКОСОР 1985/17 від 28 травня 1985 р. з метою виконання функцій моніторингу, передбачених ЕКОСОР ООН у частині IV Пакту [15, с. 11-13]. На підставі Факультативного протоколу до Міжнародного пакту про економічні, соціальні й культурні права від 10 грудня 2008 р. (набрав чинності 5 березня 2013 р.) Комітет наділено повноваженнями отримувати й розглядати повідомлення окремих осіб, які стверджують, що їхні права, закріплені Пактом, порушено. За певних обставин Комітет може також проводити розслідування грубих або систематичних порушень економічних, соціальних і культурних прав, закріплених Пактом, і розглядати міждержавні скарги [16].

Особливе місце в інституційній ланці захисту посідають «спеціальні процедури» - механізми, що запроваджуються для розгляду конкретних ситуацій у країні або тематичних питань у всіх частинах світу. Серед таких процедур варто вказати Спеціального доповідача з питання про право кожної людини на найвищий досяжний рівень фізичного і психічного здоров'я (Резолюція 2002/31 Комісії з прав людини) [17]. У зв'язку із заміною Комісії з прав людини Радою з прав людини у 2016 р. мандат Спеціального доповідача затверджено й продовжено Резолюціями Ради 6/29 від 14 грудня 2007 р., 15/22 від 6 жовтня 2010 р., 24/6 від 8 жовтня 2013 р., 33/9 від 6 жовтня 2016 р. Відповідно до мандата (Резолюція 6/29), Спеціальний доповідач зобов'язаний збирати, запитувати, отримувати й обмінюватися інформацією з усіх відповідних джерел, включаючи уряди, міжурядові та неурядові організації, про реалізацію права кожної людини на найвищий досяжний рівень фізичного і психічного здоров'я, а також про політику, призначену для досягнення пов'язаних зі здоров'ям Цілей тисячоліття в галузі розвитку; розвивати постійний діалог та обговорювати можливі галузі співробітництва з усіма відповідними суб'єктами, включаючи уряди, відповідні органи ООН, спеціалізовані установи та програми, зокрема Всесвітню організацію охорони здоров'я й Об'єднану програму ООН з ВІЛ/СНІДу, а також неурядові організації та міжнародні фінансові інститути; доповідати про стан у всьому світі щодо реалізації права кожної людини на найвищий досяжний рівень фізичного і психічного здоров'я та про події, пов'язані із цим правом, у тому числі про закони, політику й передову практику, найбільш корисні для його використання, й перешкоди, що зустрічаються на національному та міжнародному рівнях для його здійснення; надавати рекомендації про належні заходи щодо заохочення й захисту реалізації права кожної людини на найвищий досяжний рівень фізичного і психічного здоров'я $з$ метою підтримки зусиль держав у зміцненні громадського здоров'я; надавати щорічну доповідь Раді $з$ прав людини і проміжну доповідь Генеральній Асамблеї про його діяльність, висновки й рекомендації [18].

Для розгляду індивідуальних скарг необхідно надати Спеціальному доповідачу: 1) відомості про потенційних жертв (індивід, спільнота, група тощо). У цьому зв'язку варто також надати згоду потенційної жертви або їі близького родича чи законного представника, вказавши, що вони знають і згодні з тим, що інформація щодо їхньої справи буде передана Спеціальному доповідачу, вони розуміють наслідки можливих дій відповідно до його мандату; 2) інформацію про правопорушника (-ків), включаючи недержавних суб'єктів, якщо це необхідно; 3) відомості про заявника (особу (осіб) або організацію (іï) (ця інформація залишається конфіденційною). Крім того, під час подачі заяви заявник може вказати інформацію, яку він бажає залишити конфіденційною й не розкритою в публічному звіті; 3) дату, місце й опис обставин інциденту (ів) або порушення тощо.

Крім розгляду індивідуальних скарг, Спеціальний доповідач також направляє державам листи про законодавчі, політичні та інституційні засади, що стосуються права на здоров'я, які не відповідають міжнародним стандартам. Це включає листи, що стосуються міжнародного співробітництва і транснаціональних угод, у тому числі торговельних та інвестиційних угод.

Проведене дослідження дало підстави для вироблення практичних рекомендацій, спрямованих на вдосконалення чинних міжнародних актів загального характеру в галузі прав людини, 
зокрема вважаємо за доцільне доповнити Конвенцію 1950 р. статтею про право на здоров'я, що дасть змогу особам, зокрема літнім людям, захищати це право в ЄСПЛ, який є одним із дієвих i доступних регіональних судових органів, не через призму положень інших статей, а посилаючись на чітко визначене конвенційне право. Зважаючи на ту обставину, що міжнародною спільнотою створено інституційні структури захисту, в тому числі й спеціалізовані, варто посилити на національному рівні інформаційний складник доведення до відома літніх людей інформації про наявність таких інституцій, процедуру подачі скарги та забезпечити надання безоплатної правової допомоги задля реалізації такої можливості.

Висновки. Право на забезпечення здоров'я є невід'ємним складником прав людини, важливим компонентом людського буття, воно є вкрай значимим для літніх людей, які через свій вік, фізіологічні властивості тощо позбавляються можливості повноцінно функціонувати. Крім того, суттєво ускладнюють і без того важке становище цієї категорії осіб інвалідність, міграція, гуманітарні катастрофи тощо. Варто констатувати, що міжнародним співтовариством створено грунтовну правову основу в галузі захисту осіб похилого віку, реалізація якої покладається на держави. Виходячи із цього, національні системи охорони здоров'я повинні переформатовуватися, бути гнучкими і вчасно реагувати на виникнення нових проблем. Насамперед варто акцентувати увагу на належному функціонуванні медичних закладів, власне на наданні невідкладної медичної допомоги; проведенні профілактичних заходів, що сприяють здоровому способу життя; підготовці медичного персоналу; у разі браку медичного персоналу варто запроваджувати надання медичних послуг за допомогою інформаційно-комунікаційних технологій (на рівні консультацій, доставки лікарських засобів тощо); у разі необхідності доцільно поєднувати надання різних допоміжних послуг (наприклад, охорону здоров'я та соціальну допомогу), вони повинні бути ретельно скоординовані або інтегровані для ефективного задоволення потреб окремої особи; задля покращення надання медичних послуг варто запровадити посади незалежних консультантів, які дадуть людям змогу справлятися зі складністю послуг і направляти їх до відповідних ресурсів, як служб, так і фахівців; на національному рівні повинна бути налагоджена система розроблення, реалізації та оцінювання медичних послуг, до якої безпосередньо повинні бути долучені люди похилого віку, сім’ї, медичні працівники.

\section{Список використаних джерел:}

1. Всеобщая декларация прав человека 1948 г. URL: https://www.un.org/ru/documents/decl_ conv/declarations/declhr.shtml2 (дата звернення: 22.09.2019).

2. Международный пакт об экономических, социальных и культурных правах 1966 г. URL: https://www.un.org/ru/documents/decl_conv/co2ventions/pactecon.shtml (дата звернення: 21.09.2019).

3. Преобразование нашего мира: Повестка дня в области устойчивого развития на период до 2030 г. : Резолюция A/RES/70/1, принятая Генеральной Ассамблеей 25 сентября 2015 г. URL: https://unctad.org/meetings/en/SessionalDocuments/ares70d1_ru.pdf (дата звернення: 20.09.2019).

4. Декларация по проблемам старения, принята Резолюцией 47/5 Генеральной Ассамблеи от 16 октября 1992 г. URL: https://www.un.org/ru/documents/decl_conv/declarations/declold.shtml (дата звернення: 12.09.2019).

5. Принципы Организации Объединенных Наций в отношении пожилых людей «Сделать полноценной жизнь лиц преклонного возраста» (Резолюция 46/91 Генеральной Ассамблеи от 16 декабря 1991 г.). URL: https://www.un.org/ru/documents/decl_conv/conventions/oldprinc.shtml (дата звернення: 23.09.2019).

6. Мадридский международный план действий по проблемам старения 2002 г. URL: https://www.un.org/ru/documents/decl_conv/declarations/pdf/ageing_progr.pdf (дата звернення: 23.09.2019).

7. Свропейська соціальна хартія (переглянута) Страсбург, 3 травня 1996 р. URL: https://zakon.rada.gov.ua/laws/show/994_062 (дата звернення: 23.09.2019).

8. Charter of fundamental rights of the European Union. URL: https://www.europarl.europa.eu/ charter/pdf/text_en.pdf (дата звернення: 24.09.2019).

9. Международные договоры по правам человека, подборка замечаний общего порядка и общих рекомендаций, принятых договорными органами по правам человека. HRI/GEN/1/Rev.9. 2008. 27 May. Vol. I. 340 c.

10. Конвенція про захист прав людини і основоположних свобод. URL: https://zakon.rada. gov.ua/laws/show/995_004 (дата звернення: 22.09.2019). 
11. Практичний посібник щодо прийнятності заяв Європейським судом з прав людини [Рада Європи/Європейський суд з прав людини] 2011 p. URL: http://unba.org.ua/assets/uploads/ legislations/human-rights/echr-admissibility-guide.pdf (дата звернення: 12.09.2019).

12. Elderly people and the European Convention on Human Rights Right to life (Article 2 of the European Convention on Human Rights). URL: https://www.echr.coe.int/Documents/FS_Elderly_ ENG.pdf (дата звернення: 12.09.2019).

13. Steering Committee for Human Rights (CDDH) Information on the general measures taken for the purpose of execution of the relevant judgments of the European Court of Human Rights related to older persons 89th meeting Strasbourg, 19-22 June 2018. URL: https://rm.coe.int/factsheet-elderlypeople-and-the-echr/168079273d (дата звернення: 12.09.2019).

14. Международный пакт об экономических, социальных и культурных правах. URL: http://www.un.org/ru/documents/decl_conv/conventions/pactecon.shtml (дата звернення: 14.09.2019).

15. ЭКОСОС ООН. Отдельные резолюции и решения Экономического и Социального Совета, касающиеся осуществления Международного пакта об экономических, социальных и культурных правах. URL: https://digitallibrary.un.org/record/58615/files/E_C.12_1989_4-RU.pdf (дата звернення: 15.09.2019).

16. Факультативний протокол до Міжнародного пакту про економічні, соціальні і культурні права. URL: https://zakon.rada.gov.ua/laws/show/995_i50 (дата звернення: 15.09.2019).

17. The right of everyone to the enjoyment of the highest attainable standard of physical and mental health Commission on Human Rights resolution 2002/31. URL: ap.ohchr.org > resolutions > E-CN_4-RES-2002-31 (дата звернення: 22.09.2019).

18. Resolution 6/29. Right of everyone to the enjoyment of the highest attainable standard of physical and mental health. URL: https://ap.ohchr.org/documents/E/HRC/resolutions/A_HRC_ RES_6_29.pdf (дата звернення: 22.09.2019). 